\title{
LANTHANIDE ALKOXIDES-III.* FOUR-COORDINATE ANIONIC NEODYMIUM(III) ALKOXIDES AND AMIDES
}

\author{
FRANK T. EDELMANN, $\dagger$ ALEXANDER STEINER and DIETMAR STALKE \\ Institut für Anorganische Chemie der Universität Göttingen, Tammannstr. 4, \\ D-37077 Göttingen, F. R. G.
}

and

\section{JOHN W. GILJE}

Department of Chemistry, University of Hawaii at Manoa, 2545 The Mall, Honolulu, HI 96822, U.S.A.

and

\section{SUSAN JAGNER and MIKAEL HÅKANSSON}

Department of Inorganic Chemistry, Chalmers University of Technology and University of Göteborg, S-41296 Göteborg, Sweden

(Received 10 September 1993; accepted 28 September 1993)

\begin{abstract}
Tetracoordinate anionic neodymium(III) alkoxides and amides are obtained by adduct formation of $\mathrm{Nd}\left[\mathrm{OC}\left({ }^{\mathrm{B}} \mathrm{Bu}\right)_{3}\right]_{3}(\mathbf{1})$ and $\mathrm{Nd}\left[\mathrm{N}\left(\mathrm{SiMe}_{3}\right)_{2}\right]_{3}$ (2) with either $\mathrm{LiCl}$ or $\mathrm{LiOSiMe}_{3}$. The compounds (THF) $)_{3} \mathrm{Li}(\mu-\mathrm{Cl}) \mathrm{Nd}\left[\mathrm{OC}\left({ }^{\mathrm{B}} \mathrm{Bu}\right)_{3}\right]_{3} \quad(3),(\mathrm{THF})_{3} \mathrm{Li}(\mu-\mathrm{Cl}) \mathrm{Nd}$ $\left[\mathrm{N}\left(\mathrm{SiMe}_{3}\right)_{2}\right]_{3}$ (4) and $\left[\mathrm{Li}(\mathrm{THF})_{4}\right]\left[\left\{\left(\mathrm{Me}_{3} \mathrm{Si}\right)_{2} \mathrm{~N}\right\}_{3} \mathrm{Nd}\left(\mathrm{OSiMe}_{3}\right)\right]$ (5) have been characterized by single-crystal $\mathrm{X}$-ray analyses.
\end{abstract}

There is a growing interest in lanthanide alkoxide and amide chemistry. In part this is motivated by their potential use as precursors for oxide materials, which include high temperature superconductors and optical materials. ${ }^{2-4}$ The most common preparation of these alkoxides and amides involves the metathesis reaction of a lanthanide halide with an alkali metal amide or alkoxide..$^{5-8}$ In recent years, however, it has become apparent that the partial retention of halide occurs in many cases. ${ }^{9-12}$ This has led to the isolation of many new and interesting compounds, but it is also a pernicious problem since halide-free precursors are often required for oxide preparations. ${ }^{13}$ These preparations are also commonly complicated by the formation of "ate" salts which retain some of the alkali metal, usually but not always coordinated through a bridging ligand to the lanthanide. ${ }^{14-19}$ Typical examples of such "ate" complexes are $\left[\mathrm{Li}(\mathrm{THF})_{4}\right][\mathrm{Ln}$

*For part II, see Ref. 1.

$\dagger$ Author to whom correspondence should be addressed.
$\left.\left(\mathrm{CH}_{2} \mathrm{SiMe}_{3}\right)_{4}\right]{ }^{16}\left[\mathrm{Li}(\mathrm{THF})_{4}\right]\left[\mathrm{Ln}\left\{\mathrm{CH}\left(\mathrm{SiMe}_{3}\right)_{2}\right\}_{3} \mathrm{Cl}\right]{ }^{16}$ $\left[\mathrm{Li}(\mathrm{THF})_{4}\right]\left[\operatorname{Ln}\left(2,6-\mathrm{Me}_{2} \mathrm{C}_{6} \mathrm{H}_{3}\right)_{4}\right],{ }^{17} \quad($ pmdeta $) \mathrm{Li}(\mu-$ $\mathrm{Cl}) \mathrm{Ln}\left[\mathrm{CH}\left(\mathrm{SiMe}_{3}\right)_{2}\right]_{3} \quad\left(\right.$ pmdeta $=N, N, N^{\prime}, N^{\prime \prime}, N^{\prime \prime}-$ pentamethyldiethylenetriamine $)^{18}$ and $\mathrm{K}[\mathrm{Nd}(\mathrm{O}-2,6-$ $\left.\left.{ }^{i} \operatorname{Pr}_{2} \mathrm{C}_{6} \mathrm{H}_{3}\right)_{4}\right] .{ }^{19}$ Formally, the well-investigated bis(pentamethylcyclopentadienyl)lanthanide halide derivatives $\quad\left(\mathrm{C}_{5} \mathrm{Me}_{5}\right)_{2} \mathrm{Ln}(\mu-\mathrm{Cl})_{2} \mathrm{LiL}_{2} \quad(\mathrm{~L}=\mathrm{THF}$, $\mathrm{Et}_{2} \mathrm{O}, 1 / 2 \mathrm{DME}$ ) can also be regarded as "ate" complexes. $^{20-22}$

\section{EXPERIMENTAL}

All manipulations were routinely performed under $\mathrm{N}_{2}$ using dry box and Schlenk techniques. $\mathrm{LiOSiMe}_{3},{ }^{23} \mathrm{LiOC}\left({ }^{\mathrm{B}} \mathrm{Bu}\right)_{3},{ }^{24,25} \quad \mathrm{NdCl}_{3},{ }^{26} \mathrm{Nd}$ $\left[\mathrm{N}\left(\mathrm{SiMe}_{3}\right)_{2}\right]_{3}{ }^{27,28}$ and $\mathrm{Nd}\left[\mathrm{OC}\left({ }^{\mathrm{B}} \mathrm{Bu}\right)_{3}\right]_{3}(\mathrm{THF})^{29}$ were obtained according to the literature. ${ }^{1} \mathrm{H}$ NMR and IR spectra were run on Bruker WP 80 SY and Bruker AM 250 spectrometers, respectively. Mass spectra were performed on a Varian MAT CH5 instrument. Analytical data were obtained from the analytical laboratory at the Department of Inorganic Chemistry at Göttingen. 


\section{Synthesis of $(\mathrm{THF})_{3} \mathrm{Li}(\mu-\mathrm{Cl}) \mathrm{Nd}\left[\mathrm{OC}\left({ }^{\mathrm{B}} \mathrm{Bu}\right)_{3}\right]_{3}(3)$}

Compound 3 was obtained during an attempted preparation of $\mathrm{Li}\left[\mathrm{Nd}\left\{\mathrm{OC}\left({ }^{t} \mathrm{Bu}\right)_{3}\right\}_{4}\right]$. Anhydrous $\mathrm{NdCl}_{3}(1.25 \mathrm{~g}, 5.0 \mathrm{mmol})$ was added to a solution of four equivalents of $\mathrm{LiOC}\left({ }^{\mathrm{B}} \mathrm{Bu}\right)_{3}(4.13 \mathrm{~g}, 20.0$ $\mathrm{mmol})$ in THF $\left(60 \mathrm{~cm}^{3}\right)$ at $0^{\circ} \mathrm{C}$. After stirring at room temperature for $16 \mathrm{~h}$, the mixture was filtered, the solution concentrated and cooled to $-25^{\circ} \mathrm{C}$. After $48 \mathrm{~h}$, light blue crystals $(1.30 \mathrm{~g}, 26 \%)$ had formed. M.p. $138^{\circ} \mathrm{C}$. Found: C, $60.1 ; \mathrm{H}, 10.1 ; \mathrm{Cl}$, 3.5. Calc. for $\mathrm{C}_{51} \mathrm{H}_{105} \mathrm{ClLiO}_{6} \mathrm{Nd}(1001.0)$ : C, 61.2; $\mathrm{H}, 10.6 ; \mathrm{Cl}, 3.5 \%$. IR (Nujol, $\mathrm{cm}^{-1}$ ): $3631 \mathrm{~m}, 3509$ m, $1304 \mathrm{~m}, 1261 \mathrm{~s}, 1183 \mathrm{~m}, 1060$ vs, 1038 vs, 1000 vs, $922 \mathrm{~m}, 884 \mathrm{~s}, 801 \mathrm{~s}, 673 \mathrm{~s}, 466 \mathrm{~m}, 395 \mathrm{~m} .{ }^{1} \mathrm{H}$ NMR ( $80 \mathrm{MHz}, \mathrm{C}_{6} \mathrm{D}_{6} / \mathrm{TMS}$ ext., $23^{\circ} \mathrm{C}$ ) $: \delta 6.48$ (s br, $\left.v_{1 / 2}=14 \mathrm{~Hz}, 81 \mathrm{H},{ }^{\mathrm{t}} \mathrm{Bu}\right), 3.22\left(\mathrm{~s} \mathrm{br}, v_{1 / 2}=16 \mathrm{~Hz}\right.$, 24H, THF) ppm. MS $m / z: 999\left(\mathbf{M}^{+}, 2 \%\right), 719$ $\left[(\text { tritox })_{3} \mathrm{NdCl}^{+}-\mathrm{CMe}_{3}, 2 \%\right.$ ], $57\left(\mathrm{CMe}_{3}{ }^{+}, 100 \%\right)$.

\section{Synthesis of $(\mathrm{THF})_{3} \mathrm{Li}(\mu-\mathrm{Cl}) \mathrm{Nd}\left[\mathrm{N}\left(\mathrm{SiMe}_{3}\right)_{2}\right]_{3}$ (4)}

Compound $\mathbf{4}$ was isolated in very small amounts $(<10 \mathrm{mg}$ ) as a less soluble by-product during a preparation of $\mathrm{Nd}\left[\mathrm{N}\left(\mathrm{SiMe}_{3}\right)_{2}\right]_{3}$ according to the literature procedure. Blue crystals, m.p. $86^{\circ} \mathrm{C}$. Found: $\mathrm{C}, 39.5 ; \mathrm{H}, 8.6 ; \mathrm{Cl}, 4.2 ; \mathrm{N}, 4.5$. Calc. for $\mathrm{C}_{30} \mathrm{H}_{78} \mathrm{ClLiN}_{3} \mathrm{NdO}_{3} \mathrm{Si}_{6}(884.1): \mathrm{C}, 40.8 ; \mathrm{H}, 8.9 ; \mathrm{Cl}$, $4.0 ; \mathrm{N}, 4.8 \%$. IR (Nujol, $\mathrm{cm}^{-1}$ ): 1243 vs, $1178 \mathrm{~m}$, $1091 \mathrm{~s}, 1047 \mathrm{~s}, 1017 \mathrm{~s}, 977 \mathrm{vs}, 890 \mathrm{~s}, 828 \mathrm{vs}, 769 \mathrm{~s}$, $684 \mathrm{~m}, 664 \mathrm{~s}, 609 \mathrm{~m}, 599 \mathrm{~s}, 380 \mathrm{~s} .{ }^{1} \mathrm{H}$ NMR $(80$ $\mathrm{MHz}, \mathrm{C}_{6} \mathrm{D}_{6} / \mathrm{TMS}$ ext., $23^{\circ} \mathrm{C}$ ): $\delta-0.73$ (s br, $\left.v_{1 / 2}=37 \mathrm{~Hz}, 12 \mathrm{H}, \mathrm{THF}\right),-1.48\left(\mathrm{~s} \mathrm{br}, v_{1 / 2}=69 \mathrm{~Hz}\right.$, $12 \mathrm{H}, \mathrm{THF}),-5.5\left(\mathrm{br}, v_{1 / 2}=308 \mathrm{~Hz}, 54 \mathrm{H}, \mathrm{SiMe}_{3}\right)$ ppm. MS $m / z: 884\left(\mathrm{M}^{+}, 25 \%\right), 812\left(\mathrm{M}^{+}-\mathrm{THF}\right.$, $13 \%), 740\left(\mathrm{M}^{+}-2 \mathrm{THF}, 12 \%\right), 281\left(\mathrm{NdNSiMe}_{3}{ }^{+}\right.$, $35 \%), 207\left(\mathrm{NdNSi}^{+}, 100 \%\right), 73\left(\mathrm{SiMe}_{3}{ }^{+}, 41 \%\right)$.

\section{Synthesis of $\left[\mathrm{Li}(\mathrm{THF})_{4}\right]\left[\left\{\left(\mathrm{Me}_{3} \mathrm{Si}\right)_{2} \mathrm{~N}\right\}_{3} \mathrm{Nd}\left(\mathrm{OSiMe}_{3}\right)\right]$} (5)

A solution of $\mathrm{LiOSiMe}_{3}(6.8 \mathrm{mmol})$ in $30 \mathrm{~cm}^{3}$ THF was freshly prepared from $1.10 \mathrm{~g}(6.8 \mathrm{mmol})$ $\mathrm{Me}_{3} \mathrm{SiOSiMe}_{3}$ and a stoichiometric amount of methyllithium. This solution was slowly added to $4.26 \mathrm{~g}(6.8 \mathrm{mmol}) \mathrm{Nd}\left[\mathrm{N}\left(\mathrm{SiMe}_{3}\right)_{2}\right]_{3}$, dissolved in 20 $\mathrm{cm}^{3}$ THF. After $16 \mathrm{~h}$ the THF was evaporated, the residue washed with $40 \mathrm{~cm}^{3}$ hexane and extracted with $30 \mathrm{~cm}^{3}$ toluene. The toluene extract was reduced to about $10 \mathrm{~cm}^{3}$ and cooled to $-25^{\circ} \mathrm{C}$. After $24 \mathrm{~h}$ the resulting pale blue crystals $(1.75 \mathrm{~g}$, $25 \%$ ) were isolated by filtration and dried in vacuo. M.p. $c a 100^{\circ} \mathrm{C}$ (dec.). Found: C, $42.8 ; \mathrm{H}, 9.3 ; \mathrm{N}$,
3.7. Calc. for $\mathrm{C}_{37} \mathrm{H}_{95} \mathrm{LiN}_{3} \mathrm{NdO}_{5} \mathrm{Si}_{7}(1010.0)$ : C, 44.0 ; $\mathrm{H}, 9.5 ; \mathrm{N}, 4.2 \%$. IR (Nujol, $\mathrm{cm}^{-1}$ ): $1270 \mathrm{~s}, 1065$ $\mathrm{m}, 1040 \mathrm{~s}, 1020 \mathrm{~s}, 930 \mathrm{~m}, 885 \mathrm{~s}, 850 \mathrm{~s}$. 'H NMR (80 $\mathrm{MHz}, \mathrm{C}_{6} \mathrm{D}_{6} / \mathrm{TMS}$ ext., $32^{\circ} \mathrm{C}$ ): 3.73 (br, $v_{1 / 2}=48$ $\mathrm{Hz}, 16 \mathrm{H}, \mathrm{THF}), 1.22$ (br, $v_{1 / 2}=24 \mathrm{~Hz}, 16 \mathrm{H}$, THF), $-3.48\left(\mathrm{br}, v_{1 / 2}=21 \mathrm{~Hz}, 54 \mathrm{H}, \mathrm{NSiMe}_{3}\right),-5.36(\mathrm{~s}$ br, $v_{1 / 2}=9 \mathrm{~Hz}, 9 \mathrm{H}, \mathrm{OSiMe}_{3}$ ) ppm. MS $m / z: 713$ $\left(\mathrm{Me}_{3} \mathrm{SiONd}\left[\mathrm{N}\left(\mathrm{SiMe}_{3}\right)_{2}\right]_{3}{ }^{+}, 2 \%\right), 553\left(\mathrm{Me}_{3} \mathrm{SiONd}\right.$ $\left.\left[\mathrm{N}\left(\mathrm{SiMe}_{3}\right)_{2}\right]_{2}{ }^{+}, 7 \%\right), 464\left(\mathrm{Nd}\left[\mathrm{N}\left(\mathrm{SiMe}_{3}\right)_{2}\right]_{2}{ }^{+}, 6 \%\right)$, $146\left(\mathrm{Si}_{2} \mathrm{Me}_{6}{ }^{+}, 100 \%\right), 73\left(\mathrm{SiMe}_{3}{ }^{+}, 5 \%\right)$.

\section{RESULTS AND DISCUSSION}

We have become interested in the formation of such "ate" complexes and in the factors which govern their formation. In this paper we would like to describe three neodymium "ate" compounds: $(\mathrm{THF})_{3} \mathrm{Li}(\mu-\mathrm{Cl}) \mathrm{Nd}\left[\mathrm{OC}\left({ }^{\mathrm{B} B u}\right)_{3}\right]_{3} \quad(3), \quad(\mathrm{THF})_{3} \mathrm{Li}(\mu-$ $\mathrm{Cl}) \mathrm{Nd}\left[\mathrm{N}\left(\mathrm{SiMe}_{3}\right)_{2}\right]_{3}$ (4) and $\left[\mathrm{Li}(\mathrm{THF})_{4}\right]\left[\left\{\left(\mathrm{Me}_{3}\right.\right.\right.$ $\left.\left.\mathrm{Si})_{2} \mathrm{~N}\right\}_{3} \mathrm{Nd}\left(\mathrm{OSiMe}_{3}\right)\right]$ (5). Formally, they are complexes of the homoleptic $\mathrm{Nd}\left[\mathrm{OC}\left({ }^{\prime} \mathrm{Bu}\right)_{3}\right]_{3}(1)$ and/or $\mathrm{Nd}\left[\mathrm{N}\left(\mathrm{SiMe}_{3}\right)_{2}\right]_{3}(\mathbf{2})$ with a halide, chlorine, to which an alkali metal, lithium, is also coordinated or with an oxygen donor, $\mathrm{OSiMe}_{3}$, to which the counter cation is unable to complex. Together, they begin to establish some of the structural trends which can be expected in the lanthanide "ate" complexes.

The compounds described here contain the bulky alkoxide and amido ligands (" $\mathrm{Bu})_{3} \mathrm{CO}^{-}$( = "tritox") and $\left(\mathrm{Me}_{3} \mathrm{Si}\right)_{2} \mathrm{~N}^{-}$. Both ligands have frequently been used to stabilize very low coordination numbers (three or four) around lanthanide atoms.

The sterically demanding tritox ligand has been shown to effectively stabilize monomeric and dimeric lanthanide alkoxides. ${ }^{29-31}$ The mononuclear neodymium derivatives $\mathrm{Nd}\left[\mathrm{OC}\left({ }^{\mathrm{t}} \mathrm{Bu}\right)_{3}\right]_{3}(\mathrm{THF})^{29}$ and $\mathrm{Nd}\left[\mathrm{OC}\left({ }^{\mathrm{H}} \mathrm{Bu}\right)_{3}\right]_{3}(\mathrm{MeCN})_{2}{ }^{31}$ have been structurally characterized by single-crystal X-ray analyses. Unsolvated $\mathrm{Ce}(\text { tritox })_{3}{ }^{30}$ and $\mathrm{Nd}(\text { tritox })_{3}(1)^{31}$ have been mentioned but not fully characterized. Presumably these molecules are dimers and contain bridging tritox ligands. Four-coordinate $\mathrm{Nd}\left[\mathrm{OC}\left({ }^{\mathrm{t}} \mathrm{Bu}\right)_{3}\right]_{3}(\mathrm{THF})$ was prepared by treatment of $\mathrm{Nd}\left[\mathrm{N}\left(\mathrm{SiMe}_{3}\right)_{2}\right]_{3}(\mathrm{THF})_{2}$ with $\left({ }^{\mathrm{t}} \mathrm{Bu}\right)_{3} \mathrm{COH}$ (molar ratio $1: 3)$ in hexane solution. ${ }^{29} \mathrm{~A}$ different neodymium tritox derivative was isolated during an attempted preparation of the "ate" complex $\mathrm{Li}[\mathrm{Nd}$ $\left.\left\{\mathrm{OC}\left({ }^{\mathrm{t}} \mathrm{Bu}\right)_{3}\right\}_{4}\right]$. Treatment of anhydrous $\mathrm{NdCl}_{3}$ with four equivalents of $\mathrm{LiOC}\left({ }^{\mathrm{t}} \mathrm{Bu}\right)_{3}$ in THF resulted in the formation of a blue solution, from which light blue crystals were isolated. This material was shown by X-ray diffraction to be the chloride-bridged "ate" complex $(\mathrm{THF})_{3} \mathrm{Li}(\mu-\mathrm{Cl}) \mathrm{Nd}\left[\mathrm{OC}\left({ }^{\mathrm{t}} \mathrm{Bu}\right)_{3}\right]_{3}(\mathbf{3})$ : 


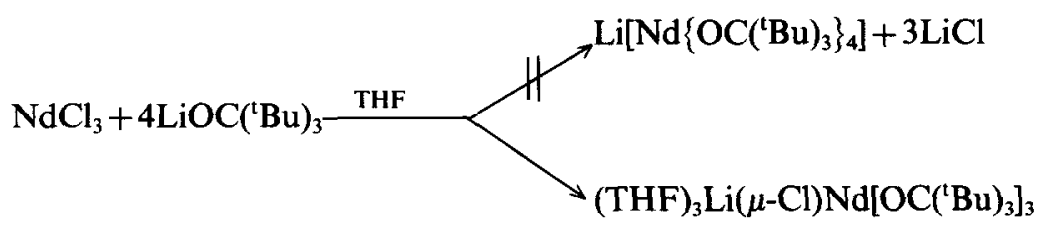

$+\mathrm{LiOC}\left({ }^{\mathrm{t}} \mathrm{Bu}\right)_{3}+2 \mathrm{LiCl}$.

compound 3 was obtained in $26 \%$ yield. The pale blue crystals of 3 are very sensitive to hydrolysis.

Tricoordination in lanthanide chemistry was first observed in the silylamide derivatives $\mathrm{Ln}\left[\mathrm{N}\left(\mathrm{SiMe}_{3}\right)_{2}\right]_{3}$ which were reported by Bradley et al. in $1973 .{ }^{27}$ The original preparation of these silylamides involves treatment of anhydrous $\mathrm{LnCl}_{3}$ with three equivalents of $\mathrm{LiN}\left(\mathrm{SiMe}_{3}\right)_{2}$ in THF solution. ${ }^{27}$ This reaction appears to be somewhat temperamental. ${ }^{31,32}$ The isolation of pure unsolvated $\mathrm{Ln}\left[\mathrm{N}\left(\mathrm{SiMe}_{3}\right)_{2}\right]_{3}$ species requires careful sublimation of the initially formed THF adducts. In some cases the sublimed materials have been found to be contaminated with either $\mathrm{LiN}\left(\mathrm{SiMe}_{3}\right)_{2}$ or $[\mathrm{LiN}$ $\left.\left(\mathrm{SiMe}_{3}\right)_{2}(\mathrm{THF})\right]_{2}$. Simple recrystallization of the crude products from hexane yields the THF solvates and in this case too the retention of $\mathrm{LiCl}$ can cause additional problems. Small amounts $(<10$ mg) of a chloride-bridged "ate" complex derived from $\mathrm{Nd}\left[\mathrm{N}\left(\mathrm{SiMe}_{3}\right)_{2}\right]_{3}(2)$ were isolated as a less soluble by-product during a large-scale preparation of 2. The blue crystals obtained from hexane were found to be suitable for X-ray diffraction and were subsequently shown to be (THF) $)_{3} \operatorname{Li}(\mu$ $\mathrm{Cl}) \mathrm{Nd}\left[\mathrm{N}\left(\mathrm{SiMe}_{3}\right)_{2}\right]_{3}(4)$. Formally, compound 4 can be regarded as a solvated adduct of $\mathbf{2}$ and $\mathrm{LiCl}$. In a separate experiment, however, it was found that pure 2 did not react with anhydrous $\mathrm{LiCl}$ in THF solution. The blue crystals of 4 are very sensitive towards air and moisture. Crystals of $\mathbf{4}$ rapidly disintegrate upon contact with trace amounts of air.

The third "ate" complex described in this work was also first observed serendipitously as a minor by-product in the preparation of 2 . A small amount of well-formed pale blue crystals was obtained which were found to be suitable for X-ray diffraction. The $\mathrm{X}$-ray analysis revealed that this material had to be formulated as $\left[\mathrm{Li}(\mathrm{THF})_{4}\right]\left[\left\{\left(\mathrm{Me}_{3}\right.\right.\right.$

* Further details of the crystal structure determinations are available upon request from the Fachinformationszentrum Karlsruhe, Gesellschaft für wissenschaftlich-technische Information $\mathrm{mbH}, \mathrm{D}-76344$ Eggenstein-Leopoldshafen, Germany, on quoting the deposition number CSD-55750, the authors and the journal citation.
$\left.\mathrm{Si})_{2} \mathrm{~N}\right\}_{3} \mathrm{Nd}\left(\mathrm{OSiMe}_{3}\right)$ ] (5). The formation of this product is easily rationalized by assuming that a small amount of $\mathrm{LiOSiMe}_{3}$ was present in the starting material $\mathrm{LiN}\left(\mathrm{SiMe}_{3}\right)_{2}$. The oxophilic character of the lanthanide ions should be responsible for the facile formation of an "ate" complex containing the $\mathrm{Me}_{3} \mathrm{SiO}^{-}$ligand. In contrast to the unsuccessful large-scale preparation of 4 , a more rational synthesis of compound 5 was achieved by addition of $\mathrm{LiOSiMe}_{3}{ }^{23}$ to 2 in THF solution. This method gave pure 5 as a pale blue crystalline solid in $25 \%$ yield :

$$
\begin{gathered}
\mathrm{Me}_{3} \mathrm{SiOSiMe}_{3}+\mathrm{MeLi} \rightarrow \mathrm{LiOSiMe}_{3}+\mathrm{SiMe}_{4} \\
\mathrm{Nd}\left[\mathrm{N}\left(\mathrm{SiMe}_{3}\right)_{2}\right]_{3}+\mathrm{LiOSiMe}_{3} \rightarrow \\
\mathbf{2}
\end{gathered}
$$$$
\left[\mathrm{Li}(\mathrm{THF})_{4}\right]\left[\left\{\left(\mathrm{Me} \mathrm{Si}_{3} \mathrm{Si}\right)_{2} \mathrm{~N}\right\}_{3} \mathrm{Nd}\left(\mathrm{OSiMe}_{3}\right)\right] \text {. }
$$$$
5
$$

These three examples illustrate the ease of formation of lanthanide "ate" complexes. Low-coordinate "ate" complexes now appear to be quite common even for the early lanthanide ions if the ligands are sufficiently bulky to prevent aggregation and formation of polymeric species.

\section{STRUCTURAL INVESTIGATIONS (TABLE 1)*}

$$
(\mathrm{THF})_{3} \mathrm{Li}(\mu-\mathrm{Cl}) \mathrm{Nd}\left[\mathrm{OC}\left({ }^{\mathrm{t}} \mathrm{Bu}\right)_{3}\right]_{3} \text { (3) (Fig. 1, Table 2) }
$$

Light blue single crystals of 3 were obtained by slow cooling of a saturated solution in THF to $-25^{\circ} \mathrm{C}$. The central neodymium atom is coordinated by three oxygen atoms of the tritox ligands and a chlorine atom bridging neodymium and lithium. This results in a slightly distorted tetrahedral coordination geometry around neodymium. The angles at neodymium range from $100.7(1)^{\circ}$ to $115.7(1)^{\circ}$. The $\mathrm{Nd}-\mathrm{O}$ distances $(2.150,2.171$ and $2.158 \AA$ ) are in good agreement with values found in previously characterized neodymium tritox derivatives \{average values : $2.150(3)-2.153(5) \AA$ in (tritox) ${ }_{3} \mathrm{Nd}(\mathrm{THF}),{ }^{29} 2.106(3) \AA$ in [(tritox $)_{2} \mathrm{Nd}(\mu$ Cl) THF $]_{2}{ }^{29}$ and $2.149(5)-2.171(5) \AA$ in (tritox $\left.)_{3} \mathrm{Nd}(\mathrm{MeCN})_{2}\right\}{ }^{31}$ All these distances can be 
Table 1. Crystallographic data for $(\mathrm{THF})_{3} \mathrm{Li}(\mu-\mathrm{Cl}) \mathrm{Nd}\left[\mathrm{OC}\left({ }^{\prime} \mathrm{Bu}\right)_{3}\right]_{3}(3)$, (THF) ${ }_{3} \mathrm{Li}(\mu-\mathrm{Cl}) \mathrm{Nd}\left[\mathrm{N}\left(\mathrm{SiMe}_{3}\right)_{2}\right]_{3}$ (4) and $\left[\mathrm{Li}(\mathrm{THF})_{4}\right]\left[\left\{\left(\mathrm{Me}_{3} \mathrm{Si}\right)_{2} \mathrm{~N}\right\}_{3} \mathrm{NdOSiMe}_{3}\right](\mathbf{5})$

\begin{tabular}{|c|c|c|c|}
\hline Compound & 3 & 4 & 5 \\
\hline Empirical formula & $\mathrm{C}_{51} \mathrm{H}_{105} \mathrm{ClLiO}_{6} \mathrm{Nd}$ & $\mathrm{C}_{30} \mathrm{H}_{78} \mathrm{ClLiN}_{3} \mathrm{NdO}_{3} \mathrm{Si}_{6} \cdot \mathrm{C}_{3} \mathrm{O}_{1.5}$ & $\mathrm{C}_{37} \mathrm{H}_{63} \mathrm{LiN}_{3} \mathrm{NdO}_{5} \mathrm{Si}_{7}$ \\
\hline Colour & Light blue & Blue & Light blue \\
\hline Crystal size (mm) & $0.5 \times 0.3 \times 0.3$ & $0.4 \times 0.4 \times 0.3$ & $0.4 \times 0.4 \times 0.1$ \\
\hline Molecular weight & 1001.0 & 944.1 & 977.7 \\
\hline Crystal system & Monoclinic & Monoclinic & Monoclinic \\
\hline Space group & $P 2_{1} / n$ & $C 2 / c$ & $P 2, / c$ \\
\hline$a(\AA)$ & $12.507(1)$ & $36.244(9)$ & $36.451(6)$ \\
\hline$b(\AA)$ & $19.639(2)$ & $16.226(4)$ & $21.927(3)$ \\
\hline$c(\AA)$ & $22.834(3)$ & $26.822(6)$ & $23.036(3)$ \\
\hline$\alpha\left({ }^{\circ}\right)$ & 90 & 90 & 90 \\
\hline$\beta\left(^{\circ}\right)$ & $97.440(10)$ & $136.299(7)$ & $107.118(8)$ \\
\hline$\gamma\left({ }^{\circ}\right)$ & 90 & 90 & 90 \\
\hline$V\left(\AA^{3}\right)$ & $5561.4(10)$ & $10898(9)$ & $17640(4)$ \\
\hline$Z$ & 4 & 8 & 12 \\
\hline$D_{\text {calc }}\left(\mathrm{g} \mathrm{cm}^{-3}\right)$ & 1.195 & 1.151 & 1.104 \\
\hline$F(000)\left(\mathrm{e}^{-}\right)$ & 2156 & 3976 & 6084 \\
\hline Diffractometer & Siemens-Stoe & Rigaku AFC6R & Siemens-Stoe \\
\hline Radiation & Mo- $K_{\alpha}$ & Mo- $K_{\alpha}$ & Mo- $K_{\alpha}$ \\
\hline$\lambda(\AA)$ & 0.71073 & 0.71069 & 0.71073 \\
\hline Temperature $\left({ }^{\circ} \mathrm{C}\right)$ & -120 & -140 & -120 \\
\hline \multicolumn{4}{|l|}{ Linear absorption coefficient } \\
\hline$\left(\mathrm{mm}^{-1}\right)$ & 1.023 & 1.165 & 1.058 \\
\hline Scan typc & $\omega-2 \theta$ & $\omega-2 \theta$ & $\omega-2 \theta$ \\
\hline $2 \theta$ range $\left({ }^{\circ}\right)$ & $8.0-48.0$ & $3.5-50.0$ & $8.0-45.0$ \\
\hline Reflections collected & 9236 & 10,192 & 26,053 \\
\hline Independent reflections & 8673 & 9895 & 22,887 \\
\hline Observed refl. $[I>3.0 \sigma(I)]$ & 7024 & 4950 & 12,085 \\
\hline Number of parameters refined & 596 & 445 & 1190 \\
\hline$R$ & 0.043 & 0.057 & 0.097 \\
\hline$R_{\mathrm{w}}$ & 0.044 & 0.067 & 0.097 \\
\hline \multicolumn{4}{|l|}{ Residual density } \\
\hline $\min \left(\mathrm{e} \AA^{-3}\right)$ & -0.64 & -0.89 & -0.92 \\
\hline $\max \left(\mathrm{e} \AA^{-3}\right)$ & 0.77 & 1.21 & 1.07 \\
\hline
\end{tabular}

considered as very short $\mathrm{Nd}-\mathrm{O}$ bonds, as the shortest $\mathrm{Nd}-\mathrm{O}$ distance reported so far is $2.03 \AA$ found in the hexanuclear alkoxide derivative $\mathrm{Nd}_{6}(\mathrm{O} \text { Pr })_{17} \mathrm{Cl}^{33}$ The values for the $\mathrm{O}-\mathrm{Nd}-\mathrm{O}$ angles (between $113.8^{\circ}$ and $115.7^{\circ}$ ) agree well with those found in other tritox derivatives of neodymium. The $\mathrm{Nd}-\mathrm{Cl}-\mathrm{Li}$ unit $\left(157.7^{\circ}\right)$ shows a significant deviation from linearity, whereas in 4 the $\mathrm{Nd}-\mathrm{Cl}-\mathrm{Li}$ unit is approximately linear $\left[175.4(6)^{\circ}\right]$. In previous studies it was demonstrated that the cone angle of tritox approaches that of cyclopentadienyl. Thus, despite its different chemical nature, this bulky alkoxide ligand can be regarded as a "steric cyclopentadienyl equivalent". ${ }^{24,29}$ For example, well-known cyclopentadienyl complexes of neodymium such as $\mathrm{Cp}_{3} \mathrm{Nd}(\mathrm{THF}){ }^{34} \quad\left[\mathrm{Cp}_{2} \mathrm{Nd}(\mu-\mathrm{Cl}) \mathrm{THF}\right]_{2}{ }^{35,36}$ and $\mathrm{Cp}_{3} \mathrm{Nd}(\mathrm{MeCN})_{2}{ }^{37}$ have parallels in tritox chemistry \{e.g. (tritox $)_{3} \mathrm{Nd}(\mathrm{THF}){ }^{29}\left[(\text { tritox })_{2} \mathrm{Nd}(\mu-\mathrm{Cl}) \mathrm{THF}\right]_{2}{ }^{29}$ and (tritox) $\left.{ }_{3} \mathrm{Nd}(\mathrm{MeCN})_{2}\right\} .{ }^{31}$ Thus a proposed ${ }^{31}$ stereochemical difference between $\mathrm{Cp}$ and tritox cannot be substantiated.

\section{$(\mathrm{THF})_{3} \mathrm{Li}(\mu-\mathrm{Cl}) \mathrm{Nd}\left[\mathrm{N}\left(\mathrm{SiMe}_{3}\right)_{2}\right]_{3}$ (4) (Fig 2, Table 3)}

Blue rectangular prisms of 4 were obtained by slow cooling of a concentrated THF solution. The overall structure of $\mathbf{4}$ is very similar to that of the chloro-bridged tritox derivative 3 . With the angles at neodymium ranging from $97.8(2)^{\circ}$ to $120.2(3)^{\circ}$, compound 4 displays a similar distortion of the tetrahedral coordination environment around the central neodymium atom. The three $\mathrm{Nd}-\mathrm{N}$ distances are almost equal and the $\mathrm{Nd}-\mathrm{Cl}[2.701(3)$ $\AA]$ and $\mathrm{Li}-\mathrm{Cl}[2.33(2) \AA]$ bond lengths agree well with the corresponding distances found for 3 $[\mathrm{Nd}-\mathrm{Cl}: 2.742(1) \AA, \mathrm{Li}-\mathrm{Cl} 2.310(10) \AA]$. The only major difference is that the $\mathrm{Nd}-\mathrm{Cl}-\mathrm{Li}$ unit in 4 is almost linear $\left[175.4(6)^{\circ}\right]$, whereas in 3 this part of the molecule is significantly bent $\left(157.7^{\circ}\right)$. Apart 




from the (THF) $)_{3} \mathrm{Li}(\mu-\mathrm{Cl}) \mathrm{Nd}\left[\mathrm{N}\left(\mathrm{SiMe}_{3}\right)_{2}\right]_{3}$ complex, the unit cell of 4 contains two groups of atoms which can presumably be assigned as disordered solvent molecules (cf. Table 1). One group [O(4), $\mathrm{O}(5), \mathrm{C}(18), \mathrm{C}(19)]$ is located around the two-fold axis with the oxygen atoms situated on the axis, site occupancies of 0.25 and 0.50 being assigned to oxygen and carbon, respectively. The centre of the other group $[\mathrm{O}(6), \mathrm{C}(25), \mathrm{C}(26)]$ coincides with a centre of symmetry. It was not possible to resolve the disorder associated with these groups to give a satisfactory chemical model, that presented here being the model giving the best crystallographic agreement.
$\left[\mathrm{Li}(\mathrm{THF})_{4}\right]\left[\left\{\left(\mathrm{Me}_{3} \mathrm{Si}\right)_{2} \mathrm{~N}\right\}_{3} \mathrm{Nd}\left(\mathrm{OSiMe}_{3}\right)\right]$ (5) (Fig. 3, Table 4)

Compound 5 crystallizes from hexane in the form of pale blue plates. When removed from the mother liquid the crystals rapidly disintegrate due to facile loss of coordinated THF. In contrast to 3 and $\mathbf{4}$, compound $\mathbf{5}$ consists of solvent-separated ion pairs. The asymmetric unit contains three crystallographically independent ion pairs. The fourcoordinate anion results from addition of an $\mathrm{Me}_{3} \mathrm{SiO}^{-}$ligand to compound 2. Three nitrogen atoms and one oxygen give rise to a distorted tetrahedral geometry at the central neodymium atom (angles at $\mathrm{Nd}: 102.9-114.6^{\circ}$ ). The $\mathrm{N}-\mathrm{Nd}-\mathrm{N}$ angles vary between $114.4^{\circ}$ and $115.0^{\circ}$. The $\mathrm{Nd}-\mathrm{N}$ distances fall in the range between 2.364 and 2.402 $\AA$, which is about $0.1 \AA$ longer than in the related compound $2(2.29 \AA){ }^{28}$ In both cases the neodymium atom forms a trigonal pyramid with the three nitrogen atoms. Compared to $\mathbf{5}$, the $\mathrm{N}-\mathrm{Nd}-\mathrm{N}$ angles in $\mathbf{2}$ are somewhat larger $\left(117.8^{\circ}\right)$, because more space is available in the coordination sphere of the neodymium atom. The same effect is found for the $\mathrm{Si}-\mathrm{N}-\mathrm{Si}$ angles: these angles are larger in 2 (av. $\left.126.4^{\circ}\right)^{28}$ compared to those in 5 (av. $122.6^{\circ}$ ). The $\mathrm{Nd}-\mathrm{O}$ distance in 5 is $2.173 \AA$. With an angle of $177.1^{\circ}$, the $\mathrm{Nd}-\mathrm{O}-\mathrm{Si}$ unit is nearly linear.

\section{CONCLUSIONS}

Three new four-coordinate anionic neodymium compounds have been prepared and structurally

Table 2. Selected bond lengths $(\AA)$ and angles $\left({ }^{\circ}\right)$ for $(\mathrm{THF})_{3} \operatorname{Li}(\mu$ $\mathrm{Cl}) \mathrm{Nd}\left[\mathrm{OC}\left({ }^{1} \mathrm{Bu}\right)_{3}\right]_{3}(3)$

\begin{tabular}{llll}
\hline $\mathrm{Nd}(1)-\mathrm{O}(1)$ & $2.150(3)$ & $\mathrm{Cl}(1)-\mathrm{Li}(1)$ & $2.310(10)$ \\
$\mathrm{Nd}(1)-\mathrm{O}(2)$ & $2.171(3)$ & $\mathrm{Li}(1)-\mathrm{O}(4)$ & $1.886(11)$ \\
$\mathrm{Nd}(1)-\mathrm{O}(3)$ & $2.158(3)$ & $\mathrm{Li}(1)-\mathrm{O}(5)$ & $1.931(12)$ \\
$\mathrm{Nd}(1)-\mathrm{Cl}(1)$ & $2.742(1)$ & $\mathrm{Li}(1)-\mathrm{O}(6)$ & $1.908(11)$ \\
$\mathrm{O}(1)-\mathrm{C}(1)$ & $1.403(5)$ & & \\
$\mathrm{O}(2)-\mathrm{C}(2)$ & $1.389(6)$ & & \\
$\mathrm{O}(3)-\mathrm{C}(3)$ & $1.396(6)$ & & \\
$\mathrm{O}(1)-\mathrm{Nd}(1)-\mathrm{O}(2)$ & $115.4(1)$ & $\mathrm{Cl}(1)-\mathrm{Li}(1)-\mathrm{O}(4)$ & $114.6(5)$ \\
$\mathrm{O}(1)-\mathrm{Nd}(1)-\mathrm{O}(3)$ & $115.7(1)$ & $\mathrm{Cl}(1)-\mathrm{Li}(1)-\mathrm{O}(5)$ & $109.7(5)$ \\
$\mathrm{O}(1)-\mathrm{Nd}(1)-\mathrm{Cl}(1)$ & $101.9(1)$ & $\mathrm{Cl}(1)-\mathrm{Li}(1)-\mathrm{O}(6)$ & $106.2(5)$ \\
$\mathrm{O}(2)-\mathrm{Nd}(1)-\mathrm{O}(3)$ & $113.8(1)$ & $\mathrm{O}(4)-\mathrm{Li}(1)-\mathrm{O}(5)$ & $108.5(5)$ \\
$\mathrm{O}(2)-\mathrm{Nd}(1)-\mathrm{Cl}(1)$ & $107.0(1)$ & $\mathrm{O}(4)-\mathrm{Li}(1)-\mathrm{O}(6)$ & $108.4(5)$ \\
$\mathrm{O}(3)-\mathrm{Nd}(1)-\mathrm{Cl}(1)$ & $100.7(1)$ & $\mathrm{O}(5)-\mathrm{Li}(1)-\mathrm{O}(6)$ & $109.5(5)$ \\
$\mathrm{Nd}(1)-\mathrm{O}(1)-\mathrm{C}(1)$ & $170.2(3)$ & & \\
$\mathrm{Nd}(1)-\mathrm{O}(2)-\mathrm{C}(2)$ & $170.0(3)$ & & \\
$\mathrm{Nd}(1)-\mathrm{O}(3)-\mathrm{C}(3)$ & $170.4(3)$ & & \\
$\mathrm{Nd}(1)-\mathrm{Cl}(1)-\mathrm{Li}(1)$ & $157.7(3)$ & & \\
\hline
\end{tabular}


Table 3. Selected bond lengths $(\AA)$ and angles $\left({ }^{\circ}\right)$ for $(\mathrm{THF})_{3} \operatorname{Li}(\mu-$ $\mathrm{Cl}) \mathrm{Nd}\left[\mathrm{N}\left(\mathrm{SiMe}_{3}\right)_{2}\right]_{3}(\mathbf{4})$

\begin{tabular}{llll}
\hline $\mathrm{Nd}-\mathrm{N}(1)$ & $2.324(8)$ & $\mathrm{N}(1)-\mathrm{Si}(1)$ & $1.712(9)$ \\
$\mathrm{Nd}-\mathrm{N}(2)$ & $2.335(8)$ & $\mathrm{N}(1)-\mathrm{Si}(2)$ & $1.724(8)$ \\
$\mathrm{Nd}-\mathrm{N}(3)$ & $2.348(8)$ & $\mathrm{N}(2)-\mathrm{Si}(3)$ & $1.710(8)$ \\
$\mathrm{Nd}-\mathrm{Cl}$ & $2.701(3)$ & $\mathrm{N}(2)-\mathrm{Si}(4)$ & $1.700(8)$ \\
$\mathrm{Cl}-\mathrm{Li}$ & $2.33(2)$ & $\mathrm{N}(3)-\mathrm{Si}(5)$ & $1.704(9)$ \\
$\mathrm{Li}-\mathrm{O}(1)$ & $1.94(2)$ & $\mathrm{N}(3)-\mathrm{Si}(6)$ & $1.712(9)$ \\
$\mathrm{Li}-\mathrm{O}(2)$ & $1.88(2)$ & & \\
$\mathrm{Li}-\mathrm{O}(3)$ & $1.91(2)$ & & \\
& & & \\
$\mathrm{N}(1)-\mathrm{Nd}-\mathrm{N}(2)$ & $115.8(3)$ & $\mathrm{Cl}-\mathrm{Li}-\mathrm{O}(1)$ & $107(1)$ \\
$\mathrm{N}(1)-\mathrm{Nd}-\mathrm{N}(3)$ & $117.9(3)$ & $\mathrm{Cl}-\mathrm{Li}-\mathrm{O}(2)$ & $109(1)$ \\
$\mathrm{N}(1)-\mathrm{Nd}-\mathrm{Cl}$ & $98.8(2)$ & $\mathrm{Cl}-\mathrm{Li}-\mathrm{O}(3)$ & $114(1)$ \\
$\mathrm{N}(2)-\mathrm{Nd}-\mathrm{N}(3)$ & $120.2(3)$ & $\mathrm{O}(1)-\mathrm{Li}-\mathrm{O}(2)$ & $108(1)$ \\
$\mathrm{N}(2)-\mathrm{Nd}-\mathrm{Cl}$ & $98.4(2)$ & $\mathrm{O}(1)-\mathrm{Li}-\mathrm{O}(3)$ & $110(1)$ \\
$\mathrm{N}(3)-\mathrm{Nd}-\mathrm{Cl}$ & $97.8(2)$ & $\mathrm{O}(2)-\mathrm{Li}-\mathrm{O}(3)$ & $109(1)$ \\
$\mathrm{Nd}-\mathrm{N}(1)-\mathrm{Si}(1)$ & $116.6(4)$ & $\mathrm{Si}(1)-\mathrm{N}(1)-\mathrm{Si}(2)$ & $121.3(5)$ \\
$\mathrm{Nd}-\mathrm{N}(1)-\mathrm{Si}(2)$ & $122.1(4)$ & $\mathrm{Si}(3)-\mathrm{N}(2)-\mathrm{Si}(4)$ & $123.6(5)$ \\
$\mathrm{Nd}-\mathrm{N}(2)-\mathrm{Si}(3)$ & $115.8(4)$ & $\mathrm{Si}(5)-\mathrm{N}(3)-\mathrm{Si}(6)$ & $122.2(5)$ \\
$\mathrm{Nd}-\mathrm{N}(2)-\mathrm{Si}(4)$ & $120.5(4)$ & & \\
$\mathrm{Nd}-\mathrm{N}(3)-\mathrm{Si}(5)$ & $118.3(4)$ & & \\
$\mathrm{Nd}-\mathrm{N}(3)-\mathrm{Si}(6)$ & $119.4(4)$ & & \\
$\mathrm{Nd}-\mathrm{Cl}-\mathrm{Li}$ & $175.4(6)$ & & \\
& & &
\end{tabular}

Table 4. Selected bond lengths $(\AA)$ and angles $\left({ }^{\circ}\right)$ for $\left[\mathrm{Li}(\mathrm{THF})_{4}\right]$ $\left[\left\{\left(\mathrm{Me}_{3} \mathrm{Si}\right)_{2} \mathrm{~N}\right\}_{3} \mathrm{Nd}\left(\mathrm{OSiMe}_{3}\right)\right](\mathbf{5})$

\begin{tabular}{|c|c|c|c|c|c|}
\hline $\mathrm{Nd}(1)-\mathrm{O}(1)$ & \multicolumn{2}{|c|}{$2.173(11)$} & $O(1)-S i(17)$ & \multicolumn{2}{|c|}{$1.618(13)$} \\
\hline $\mathrm{Nd}(1)-\mathrm{N}(11)$ & \multicolumn{2}{|c|}{$2.402(10)$} & $\mathrm{N}(11)-\mathrm{Si}(11)$ & \multicolumn{2}{|c|}{$1.707(12)$} \\
\hline $\mathrm{Nd}(1)-\mathrm{N}(12)$ & \multicolumn{2}{|c|}{$2.364(11)$} & $\mathrm{N}(11)-\mathrm{Si}(12)$ & \multicolumn{2}{|c|}{$1.691(12)$} \\
\hline$N d(1)-N(13)$ & \multicolumn{2}{|c|}{$2.382(13)$} & $\begin{array}{l}\mathrm{N}(12)-\mathrm{Si}(13) \\
\mathrm{N}(12)-\mathrm{Si}(14)\end{array}$ & \multicolumn{2}{|c|}{$1.741(15)$} \\
\hline $\begin{array}{l}\mathrm{Li}(1)-\mathrm{O}(41) \\
\mathrm{Li}(1)-\mathrm{O}(42) \\
\mathrm{Li}(1)-\mathrm{O}(43) \\
\mathrm{Li}(1)-\mathrm{O}(44)\end{array}$ & $\begin{array}{l}1.92 \\
1.83 \\
1.93 \\
1.86\end{array}$ & & & & \\
\hline \multicolumn{3}{|c|}{$\mathrm{N}(11)-\mathrm{Nd}(1)-\mathrm{N}(12) \quad 114.6(4)$} & \multicolumn{2}{|c|}{$\mathrm{Nd}(1)-\mathrm{N}(11)-\mathrm{Si}(11)$} & $121.7(5)$ \\
\hline \multicolumn{2}{|c|}{$N(11)-N d(1)-N(13)$} & $115.0(4)$ & \multicolumn{2}{|c|}{$\mathrm{Nd}(1)-\mathrm{N}(11)-\mathrm{Si}(12)$} & $114.4(6)$ \\
\hline \multicolumn{2}{|c|}{$\mathrm{N}(11)-\mathrm{Nd}(1)-\mathrm{O}(1)$} & $102.9(4)$ & \multicolumn{2}{|c|}{$\mathrm{Nd}(1)-\mathrm{N}(12)-\mathrm{Si}(13)$} & $114.0(6)$ \\
\hline \multicolumn{2}{|c|}{$\mathbf{N}(12)-\mathrm{Nd}(1)-\mathbf{N}(13)$} & $114.4(4)$ & \multicolumn{2}{|c|}{$\mathrm{Nd}(1)-\mathrm{N}(12)-\mathrm{Si}(14)$} & $125.3(7)$ \\
\hline \multicolumn{2}{|c|}{$\mathrm{N}(12)-\mathrm{Nd}(1)-\mathrm{O}(1)$} & $104.2(4)$ & \multicolumn{2}{|c|}{$\mathrm{Nd}(1)-\mathrm{N}(13)-\mathrm{Si}(15)$} & $112.6(7)$ \\
\hline \multicolumn{2}{|c|}{$\mathrm{N}(13)-\mathrm{Nd}(1)-\mathrm{O}(1)$} & $103.7(4)$ & \multicolumn{2}{|c|}{$\begin{array}{l}\mathrm{Nd}(1)-\mathrm{N}(13)-\mathrm{Si}(16) \\
\mathrm{Nd}(1)-\mathrm{O}(1)-\mathrm{Si}(17)\end{array}$} & $\begin{array}{l}123.8(6) \\
177.1(6)\end{array}$ \\
\hline \multicolumn{2}{|c|}{$O(41)-\mathrm{Li}(1)-O(42)$} & $109(2)$ & \multicolumn{2}{|c|}{$\mathrm{Si}(11)-\mathrm{N}(11)-\mathrm{Si}(12)$} & $123.6(7)$ \\
\hline \multicolumn{2}{|c|}{$\mathrm{O}(41)-\mathrm{Li}(1)-\mathrm{O}(43)$} & $104(2)$ & \multirow{2}{*}{\multicolumn{2}{|c|}{$\begin{array}{l}\mathrm{Si}(13)-\mathrm{N}(12)-\mathrm{Si}(14) \\
\mathrm{Si}(15)-\mathrm{N}(13)-\mathrm{Si}(16)\end{array}$}} & $120.4(7)$ \\
\hline \multirow{2}{*}{\multicolumn{2}{|c|}{$\begin{array}{l}O(41)-\mathrm{Li}(1)-O(44) \\
\mathrm{O}(42)-\mathrm{Li}(1)-O(43)\end{array}$}} & $102(2)$ & & & $123.3(8)$ \\
\hline & & $114(2)$ & & \\
\hline \multicolumn{2}{|c|}{$O(42)-\mathrm{Li}(1)-O(44)$} & $113(2)$ & & & \\
\hline \multicolumn{2}{|c|}{$O(43)-\mathrm{Li}(1)-O(44)$} & $114(2)$ & & & \\
\hline
\end{tabular}



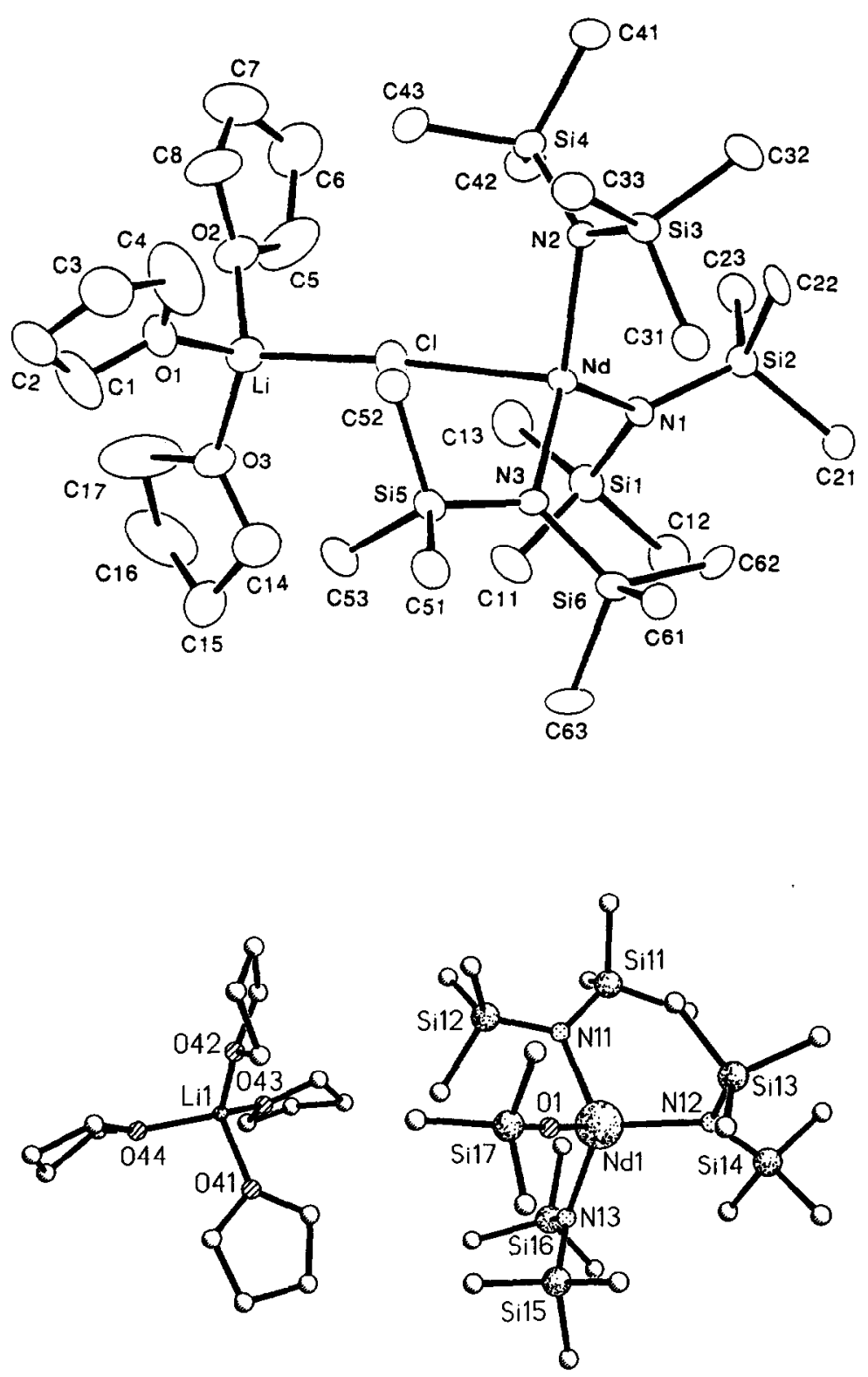

characterized in this study: (THF) $)_{3} \mathrm{Li}(\mu$ $\mathrm{Cl}) \mathrm{Nd}\left[\mathrm{OC}\left({ }^{\mathrm{t}} \mathrm{Bu}\right)_{3}\right]_{3} \quad(3), \quad(\mathrm{THF})_{3} \mathrm{Li}(\mu-\mathrm{Cl}) \mathrm{Nd}[\mathrm{N}(\mathrm{Si}$ $\left.\left.\mathrm{Me}_{3}\right)_{2}\right]_{3}$ (4) and $\left[\mathrm{Li}(\mathrm{THF})_{4}\right]\left[\left\{\left(\mathrm{Me}_{3} \mathrm{Si}\right)_{2} \mathrm{~N}\right\}_{3} \mathrm{Nd}(\mathrm{OSi}\right.$ $\left.\mathrm{Me}_{3}\right)$ ] (5). All three compounds are monomeric alkoxide or amide derivatives of an early lanthanide metal. Together they demonstrate that very low coordination numbers are becoming a familiar sight in lanthanide coordination chemistry, provided that the ancillary ligands are sufficiently bulky. Using the sterically highly demanding alkoxide and amide ligands ${ }^{\mathrm{t}} \mathrm{Bu}_{3} \mathrm{CO}^{-}$and $\left(\mathrm{Me}_{3} \mathrm{Si}\right)_{2} \mathrm{~N}^{-}$, four-coordinate derivatives are available even for the early lanthanides, i.e. the largest ions in the series.

\section{REFERENCES}

1. A. Edelmann, J. W. Gilje and F. T. Edelmann, Polyhedron 1992, 11, 2421.

2. L. G. Hubert-Pfalzgraf, New J. Chem. 1987, 662.

3. D. C. Bradley, Chem. Rev. 1989, 89, 1317.

4. R. J. Cava, Spektr. Wiss. 1990, 118.

5. D. C. Bradley, R. C. Mehrotra and D. P. Gaur, Metal Alkoxides. Academic Press, London (1978).

6. P. S. Gradeff, F. G. Schreiber, K. C. Brooks and R. E. Sievers, Inorg. Chem. 1985, 24, 1110.

7. P. S. Gradeff, F. G. Schreiber and H. Mauermann, J. Less-Common Met. 1986, 126, 335.

8. W. J. Evans, T. J. Deeming, J. M. Olofson and J. W. Ziller, Inorg. Chem. 1989, 28, 4027. 
9. R. A. Andersen, D. H. Templeton and A. Zalkin, Inorg. Chem. 1978, 17, 1962.

10. W. J. Evans, M. S. Sollberger and T. P. Hanusa, J. Am. Chem. Soc. 1988, 110, 1841.

11. W. J. Evans and M. S. Sollberger, Inorg. Chem. 1988, 27, 4417.

12. W. J. Evans, J. M. Olofson and J. W. Ziller, J. Am. Chem. Soc. 1990, 112, 2308.

13. W. A. Herrmann, R. Anwander, M. Kleine and W. Scherer, Chem. Ber. 1992, 125, 1971.

14. K. G. Caulton and I. G. Hubert-Pfalzgraf, Chem. Rev. 1990, 90, 969.

15. P. B. Hitchcock, M. F. Lappert and A. Singh, $J$. Chem. Soc., Chem. Commun. 1983, 1499.

16. J. L. Atwood, W. E. Hunter, R. D. Rogers, J. Holton, J. McMeeking, R. Pearce and M. F. Lappert, $J$. Chem. Soc., Chem. Commun. 1978, 140.

17. S. A. Cotton, F. A. Hart, M. B. Hursthouse and A. J. Welch, J. Chem. Soc., Chem. Commun. 1972, 1225.

18. J. L. Atwood, M. F. Lappert, R. G. Smith and H. Zhang, J. Chem. Soc., Chem. Commun. 1988, 1308.

19. D. L. Clark, J. G. Watkin and J. C. Huffman, Inorg. Chem. 1992, 31, 1554.

20. A. L. Wayda and W. J. Evans, Inorg. Chem. 1980, 19, 2190.

21. T. D. Tilley and R. A. Andersen, Inorg. Chem. 1981, 20, 3267.

22. M. D. Rausch, K. J. Moriarty, J. L. Atwood, J. A. Weeks, W. E. Hunter and H. G. Brittain, Organometallics 1986, 5, 1281.

23. D. Seyferth and D. L. Alleston, Inorg. Chem. 1963, 2, 418 .
24. T. V. Lubben, P. T. Wolczanski and G. D. Van Duyne, Organometallics 1984, 3, 977.

25. G. Beck, P. B. Hitchcock, M. F. Lappert and I. A. MacKinnon, J. Chem. Soc., Chem. Commun. 1989, 1312.

26. J. H. Freeman and M. L. Smith, J. Inorg. Nucl. Chem. 1958, 7, 224.

27. D. C. Bradley, J. S. Ghotra and F. A. Hart, J. Chem. Soc., Dalton Trans. 1973, 1021.

28. R. A. Andersen, D. H. Templeton and A. Zalkin, Inorg. Chem. 1987, 17, 2317.

29. M. Wedler, J. W. Gilje, U. Pieper, D. Stalke, M. Noltemeyer and F. T. Edelmann, Chem. Ber. 1991, $124,1163$.

30. H. A. Stecher, A. Sen and A. L. Rheingold, Inorg. Chem. 1989, 28, 3280.

31. W. A. Herrmann, R. Anwander and W. Scherer, Chem. Ber. 1992, 125, 1971.

32. R. L. LaDuca and P. T. Wolczanski, Inorg. Chem. 1992, 31, 1313.

33. R. A. Andersen, D. H. Templeton and A. Zalkin, Inorg. Chem. 1978, 17, 1962.

34. F. Benetollo, G. Bombieri, C. B. Castellani, W. Jahn and R. D. Fischer, Inorg. Chim. Acta 1984, 95, L7.

35. Q. Shen, W. Chen, Y. Yin and C. Shan, Pure Appl. Chem. 1988, 60, 1251.

36. Z. Jin, Y. Liu and W. Chen, Scientia Sinica 1987, 1, 1.

37. H. Schulz, H. Reddmann and H.-D. Amberger, $J$. Organomet. Chem. 1992, 440, 317. 